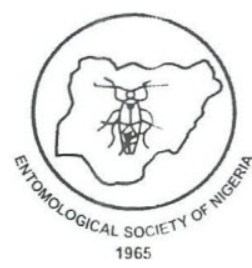

Nigerian Journal of Entomology

\title{
Abundance, Distribution and Diversity of Terrestrial Insects in University of Ibadan, Ibadan, Western Nigeria
}

\author{
ABAH, J. P., K.O.K POPOOLA* AND A.A. HASSAN \\ Department of Zoology, University of Ibadan, Oyo State, Nigeria.
}

\begin{abstract}
Nig.J.Entomol.33: 129-137(2017)
ABSTRACT: This study was conducted to assess the status of terrestrial insects' population in three selected sites (the Botanical Garden, Awba Dam area and the Practical Year Training Programme farmland all on University of Ibadan campus). The study was carried out from February to July, 2012. Insect samples were collected from the study sites using sweep net, pitfall trap and handpicking methods. Insects collected were identified at the Insect Museum in the Department of Crop Protection and Environmental Biology, University of Ibadan, using Standard Key and Comparative Morphology. A total of 1,524 individuals, belonging to nine orders were recorded during the study.The order Hymenoptera was observed as the most abundant while order Lepidoptera was the most diverse. Margalef's and Shannon's indices of species richness and diversity analysis showed that the Awba Dam site had the highest species richness and diversity, with Margalef's and Shannon's indices values of 4.96 and 4.36 respectively. Pearson correlation coefficient showed no significant relationship between insect abundance and temperature, relative humidity or solar radiation. But there was a significant relationship between insect abundance and months $(\mathrm{r}=0.890)$ at $p>0.05$ level.
\end{abstract}

Keywords: Terrestrial Insects, Abundance, Distribution, Diversity, University of Ibadan

\section{INTRODUCTION}

Insects are the most diverse and abundant of all groups of arthropods. Borror and Delong (1970) reported insects as the dominant group of animals on earth to date. They noted that insects by far exceed all other terrestrial animals in numbers, and they occur practically everywhere. The diversity of insects in the humid tropics has amazed biologists such as Bates, Wallace and the other 19 th century explorer naturalists (since the days of Bates, Godfray et al., 1997). Only small fractions (certainly fewer than $20 \%$ ) of tropical insects have been described by entomologists.

All the while, habitats are contracting and being destroyed at historically incomparable

*Corresponding author:

E-mail: kokpopular(a gmail.com rate (Godfray et al. 1997). Several studies have provided pieces of evidence showing that tropical insects undergo seasonal changes in abundance at least in those parts of the tropics where wet and dry seasons alternate (Davis, 1945). Denlinger (1980) pointed out that seasonality is a "conspicuous feature in the life history of many organisms". According to Owen (1972), in the humid tropics of West Africa, adults of many species of terrestrial insects occur in all the months of the year, but with seasonal peaks of abundance that are associated with the alternation of wet and dry seasons. In an area where there are well-defined seasons, the onset of the rains often results in an enormous increase in the numbers of species that have occurred at low frequencies, throughout the dry season (Aydagnhum, 2007). The study determined the 
abundance, distribution and diversity of terrestrial insect species found on the University of Ibadan Campus, Oyo State, Nigeria.

\section{MATERIALSAND METHODS}

\section{Description of Study Area}

The study was conducted at the University of Ibadan, Oyo State, Nigeria. Geographically, the University of Ibadan is situated in the South Western part of Nigeria $\left(78^{\prime} 9^{\prime \prime} \mathrm{N}, 595^{\prime} 7^{\prime \prime} \mathrm{E}\right)$ (Figure1). Ibadan is characterized by both rainy and dry seasons, with rainy and dry seasons lasting from April to October, and November to March respectively (Akoroda, 2008). The three sites used within the study location include the Botanical Garden (A), the Awba Dam area (B) and the Practical Year Training Programme (PYTP) Farmland (C). Site A (the Botanical Garden), was founded in 1948 during the establishment of the University primarily for teaching and research in Botany. It also serves for collection, raising and preservation of different plant species. The garden occupies about 40 hectares of land area. Currently, the garden houses a lot of plant diversity with about $80-100$ plant families represented. The botanical garden is mapped out into different sections, including the nursery and ornamental sections, rose garden, conserved area and others. The Awba Dam is a small man-made lake with a surface area of 6 hectares and a length of 700m (Omotosho, 1981). It was constructed in April 1964, to develop the university's internal water supply system and compliment the very limited amount supplied from Oyo State. The dam also store water for domestic consumption, laboratory use, aquaculture and to facilitate hydrobiology and ecology research projects. It is surrounded by modified tropical rainforest vegetation and as such, is rich in insect fauna.The Practical Year Training Programme (PYTP) was established in 1976 to enable the fourth year students of the Faculty of Agriculture acquire practical farming skills. The PYTP Farmland occupies about 2.5 hectares and crops such as maize, vegetables and cowpeas.

\section{Collection of Insect Samples}

Insect samples were collected fortnightly from the sampling sites, within a sampling period of six months. The standard methods employed in the collection of insect were those outlined by Youdeowei (1977) and include the use of sweep net, pitfall trap and hand picking methods. Killing jar was prepared with chloroform-soaked cotton wool for charging, with a laid plain paper on top of the wool. The Killing jar was used in killing collected insects before preservation in insectbox.

\section{Processing of Insects Collected}

After the death of the insects, they were preserved by pinning. This was done by placing the insects on a mounting stage and entomological pins were pushed vertically through the thorax of the insect specimens after which, they were left to dry. Insects collected were identified at the Insect Museum of the Department ofCrop Protection and Environmental Biology and the Museum of the Department of Zoology, University of Ibadan, using Standard Key and Comparative Morphology. The identified insect specimens were labelled using a stiff white paper mounted in an insect box. Information such as the insect species, date of collection, place of collection and the name of the collector, were included on the label(Oldroyd, 1958).

\section{Environmental Parameters Reading}

The environmental parameters taken include temperature, solar radiation and relative humidity (r.h). The daily temperature at the time of insect collection was measured using a thermometer, while data on solar radiation and relative humidity were obtained from the Geographic Information System (G.I.S) Unit of the Department of Geography, University of Ibadan. 


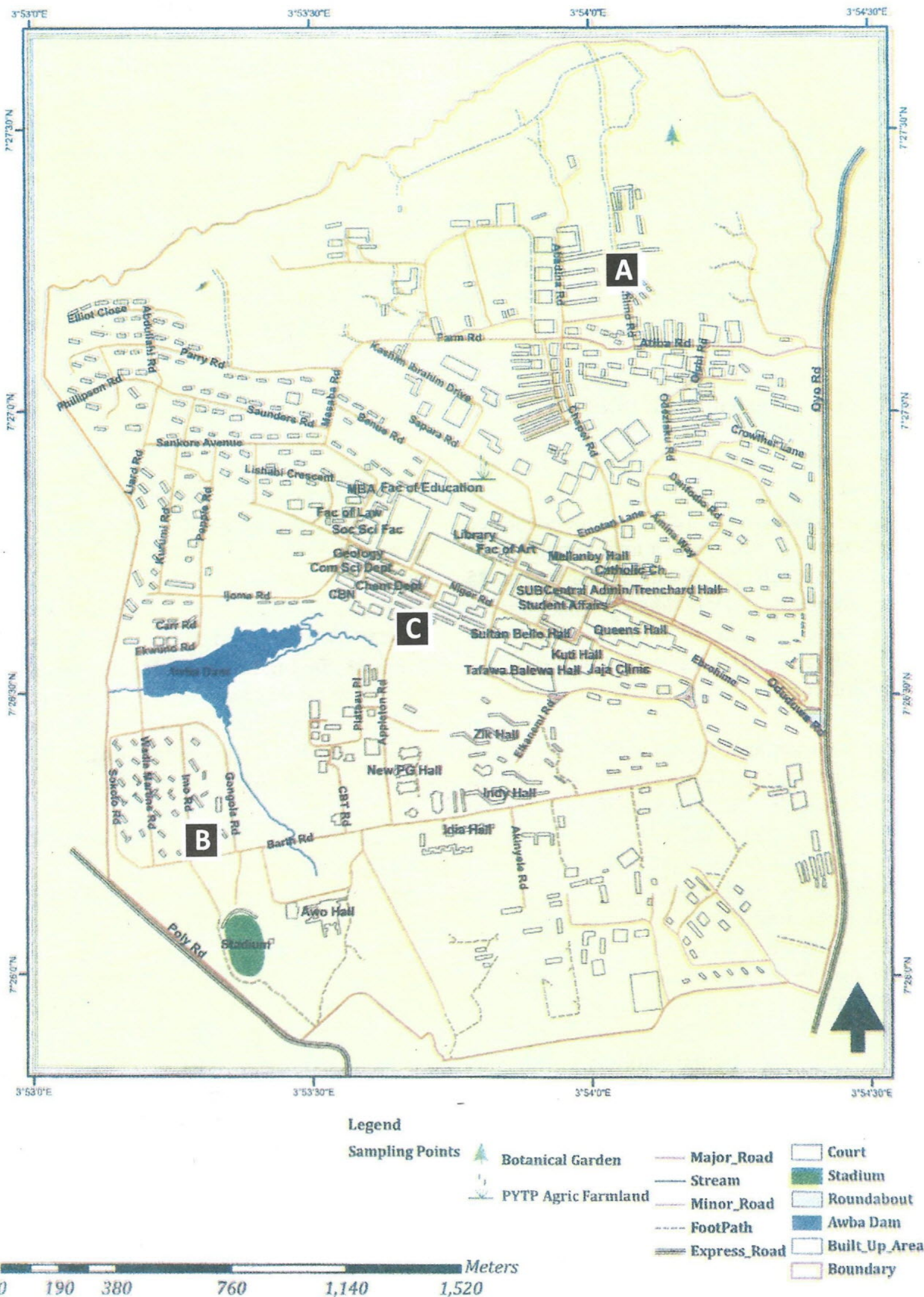

Figure 1: Map of University of Ibadan with sampling sites

A Botanical Garden

B Awba Dam

C PYTP Agric Farm 


\section{Data analysis}

Margalef's index was used to determine the species richness for each sampling site. Evenness index was used to determine the distribution of insect species within the sampling sites. The relative abundance and diversity of insects from each sampling site were computed using Shannon's diversity index $(\mathrm{H})$. Pearson correlation coefficient was used to evaluate the relationship between insect abundance per month and average temperature, relative humidity and solar radiation.

\section{RESULTS}

\section{Abundance, Distribution and Diversity of insects}

The relative abundance, distribution and diversity of insects caught during the period of study are presented in Table 1. Nine identified orders were recorded with a total population of 1,524 individuals. The Botanical Garden had 35 taxa, comprising 709 individuals; Awba Dam site had 31 taxa, consisting of 531 individuals, while the PYTP Farmland had 23 taxa, made up of 284 individuals (Table 1).

Order Hymenoptera, conspicuously represented by the genus Componotus, had $74 \%$ relative abundance in Awba Dam area, $73.61 \%$ in the Botanical Garden and $71.13 \%$ in PYTP Farmland. The Hymenopterans were evenly distributed in the sampled points. Order Lepidoptera, were also relatively well distributed in the sampled sites, with $12.68 \%$ relative abundance in the Botanical Garden, followed by PYTP Farmland (7.39\%) and lastly Awba Dam site $(3.75 \%)$. Similarly, order Odonata, solely represented by the family Libellulidae, had $16.90 \%$ relative abundance in PYTP Farmland, $7.70 \%$ in Awba Dam area and 2.96\% in the Botanical Garden (Table 1).

Order Diptera, represented by only two species Chrysomiya sp. and Sarcophaga sp. had $4.23 \%$ relative abundance in PYTP Farmland, $0.94 \%$ in Awba Dam site and $0.28 \%$ in the Botanical Garden. Order Orthoptera, was only recorded in the Botanical Garden and Awba Dam site, with $2.11 \%$ and $1.88 \%$ relative abundance respectively. In the same way, order Hemiptera, was only recorded in Awba Dam site and in the Botanical Garden, with 10.73\% and $3.52 \%$ relative abundance respectively. Similarly, the Coleopterans were only found in Awba Dam area and in the PYTP Farmland (Table 1).

Order Dictyoptera, represented by only one species Mantis sp. was found in the Botanical Garden and in PYTP Farmland. The order Neuroptera, represented by a single species Hagenomiya tristis, occurred only in the Botanical Garden(Table 1).

\section{Monthly Prevalence of Insects}

The number of insects collected per month from each of the three sampled points is shown in Figure 2. The highest number of insects was recorded in June at the Botanical Garden, while the least was obtained in February. For Awba Dam site, the highest number was obtained in July while the least was also in February. For PYTP Farmland, the highest number of insects was recorded in the month of July, while the least was in February.

\section{Species Richness and Diversity of Insects in the Sampled Sites}

The overall species richness and diversity of insects collected in the sampled sites are summarized in Table 2. Awba Dam area had the highest species richness with Margalef's index value of 4.96, followed by the Botanical Garden (2.36) and lastly the PYTP Farmland (2.14). Shannon's index $(\mathrm{H})$ value, was also highest in Awba Dam area with the value of 4.36 , followed by PYTP Farmland (2.36) and lastly, Botanical Garden (2.05). Evenness's index was similarly highest in Awba Dam area with the value of 5.62 , followed by 4.13 and 3.15 for Botanical Garden and PYTP Farmland respectively. 
Table 1: Relative Abundance and Distribution of Insects from the three Sampled Sites SAMPLED SITES

\begin{tabular}{|c|c|c|c|c|c|c|}
\hline \multirow{3}{*}{$\begin{array}{l}\text { INSECTS ORDERS } \\
\text { COLLECTED AND } \\
\text { SPECIES }\end{array}$} & \multicolumn{2}{|c|}{ A } & \multicolumn{2}{|c|}{ B } & \multicolumn{2}{|c|}{$\mathrm{C}$} \\
\hline & \multicolumn{2}{|c|}{ BOTANICAL GARDEN } & \multicolumn{2}{|c|}{ AWBA DAM AREA } & \multicolumn{2}{|c|}{ PYTP FARMLAND } \\
\hline & $\begin{array}{l}\text { Number of } \\
\text { individuals }\end{array}$ & $\begin{array}{l}\% \text { Relative } \\
\text { Abundance }\end{array}$ & $\begin{array}{l}\text { Number of } \\
\text { individuals }\end{array}$ & $\begin{array}{l}\% \text { Relative } \\
\text { Abundance }\end{array}$ & $\begin{array}{l}\text { Number of } \\
\text { individuals }\end{array}$ & $\begin{array}{l}\% \text { Relative } \\
\text { Abundance }\end{array}$ \\
\hline \multicolumn{7}{|l|}{ HYMENOPTERA } \\
\hline Componotus maculatus & 463 & 65.30 & 200 & 37.66 & 0 & 0.00 \\
\hline Componotus sp. & 52 & 7.33 & 179 & 33.71 & 181 & 63.73 \\
\hline Dorylus nigricans & 1 & 0.14 & 0 & 0.00 & 0 & 0.00 \\
\hline Sceliphrons pirifex & 0 & 0.00 & 0 & 0.00 & 8 & 2.82 \\
\hline Apis millifera & 1 & 0.14 & 10 & 1.88 & 1 & 0.35 \\
\hline X!locopa olivacea & 0 & 0.00 & 1 & 0.19 & 0 & 0.00 \\
\hline Neolaparus sp. & 2 & 0.28 & 0 & 0.00 & 3 & 1.06 \\
\hline Synagris calida & 0 & 0.00 & 0 & 0.00 & 1 & 0.35 \\
\hline Belonogaster junceus & 3 & 0.42 & 3 & 0.56 & 8 & 2.82 \\
\hline \multicolumn{7}{|l|}{ LEPIDOPTERA } \\
\hline Cataphlia florella & 48 & 6.77 & 2 & 0.38 & 0 & 0.00 \\
\hline Belenois calypso & 2 & 0.28 & 4 & 0.75 & 6 & 2.11 \\
\hline Eurema hecaba & 1 & 0.14 & 0 & 0.00 & 0 & 0.00 \\
\hline Appia sepaphia & 0 & 0.00 & 0 & 0.00 & 2 & 0.70 \\
\hline Panlymna salcippus & 4 & 0.56 & 2 & 0.38 & 2 & 0.70 \\
\hline Amauris hyalites & 2 & 0.28 & 0 & 0.00 & 3 & 1.06 \\
\hline Papilio demodecus & 3 & 0.42 & 1 & 0.19 & 0 & 0.00 \\
\hline Graphiumpolicines & 1 & 0.14 & 0 & 0.00 & 0 & 0.00 \\
\hline Precis oenone & 6 & 0.85 & 4 & 0.75 & 3 & 1.06 \\
\hline Precis octavia & 8 & 1.13 & 0 & 0.00 & 0 & 0.00 \\
\hline Precis dabius & 2 & 0.28 & 0 & 0.00 & 0 & 0.00 \\
\hline Euryphura chalcis & 6 & 0.85 & 0 & 0.00 & 0 & 0.00 \\
\hline Hypolimnas dubius & 1 & 0.14 & 0 & 0.00 & 1 & 0.35 \\
\hline Bebearia cutteri & 1 & 0.14 & 0 & 0.00 & 0 & 0.00 \\
\hline Heptis morose & 0 & 0.00 & 1 & 0.19 & 0 & 0.00 \\
\hline Aterica galena & 0 & 0.00 & 1 & 0.19 & 0 & 0.00 \\
\hline Euphaedroceres & 1 & 0.14 & 0 & 0.00 & 0 & 0.00 \\
\hline Acraeaponina & 3 & 0.42 & 4 & 0.75 & 4 & 1.41 \\
\hline Heraclia geryon & 0 & 0.00 & 1 & 0.19 & 0 & 0.00 \\
\hline Amauris niavius & 1 & 0.14 & 0 & 0.00 & 0 & 0.00 \\
\hline \multicolumn{7}{|l|}{ ODONATA } \\
\hline Palpopleura sp. & 6 & 0.85 & 9 & 1.69 & 13 & 4.58 \\
\hline Brachythemis locustris & 0 & 0.00 & 3 & 0.56 & 7 & 2.46 \\
\hline Parazyxama flavicans & 0 & 0.00 & 5 & 0.94 & 0 & 0.00 \\
\hline Palpopleura lucio & 11 & 1.55 & 5 & 0.94 & 8 & 2.82 \\
\hline Pantala flavescens & 3 & 0.42 & 16 & 3.01 & 3 & 1.06 \\
\hline Me'acne'mis rohosta & 0 & 0.00 & 0 & 0.00 & 1 & 0.35 \\
\hline ()ithetrum brachicale & 1 & 0.14 & 3 & 0.56 & 16 & 5.63 \\
\hline ORTHOPTERA & 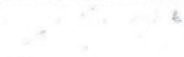 & & & & & \\
\hline Locusta migratoria & 1 & 0.14 & 0 & 0.00 & 0 & 0.00 \\
\hline Scapsipedus marginatus & 0 & 0.00 & 7 & 1.32 & 0 & 0.00 \\
\hline Zonocerus varicgatus & 14 & 1.97 & 3 & 0.56 & 0 & 0.00 \\
\hline
\end{tabular}




\section{HEMIPTERA \\ Probergrothius \\ sexpunctatus \\ Reduviidae nymph \\ Dieuches sp \\ Lygaeidae \\ Rhynocoris bicolor \\ COLEOPTERA \\ Chrv'solagria cuprina \\ Aulacophora transversa \\ Melyris abdominalis \\ Melambia striata \\ Oides ferruginea \\ DIPTERA \\ Chrysomiya sp \\ Sarcophaga sp \\ DICTYOPTERA \\ Mantis sp \\ NEUROPTERA \\ Hagenomiya tristis \\ TOTAL

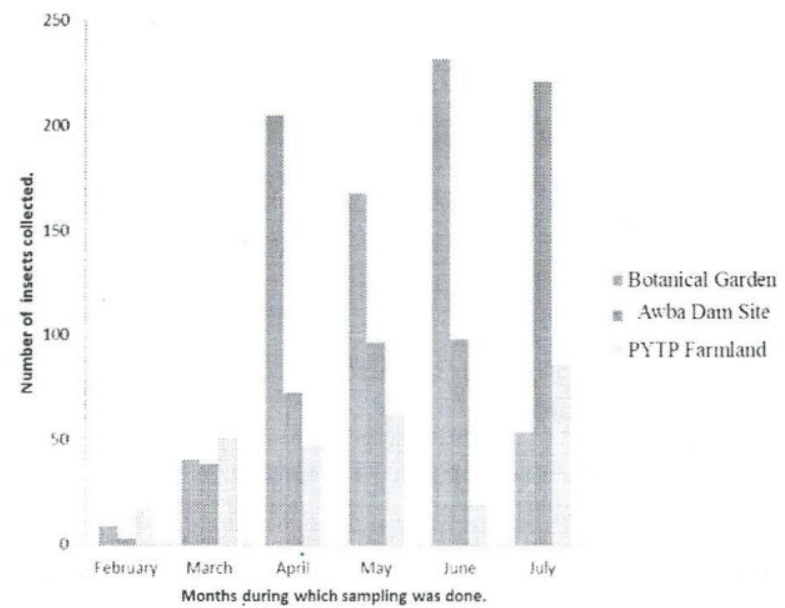

Figure 2: Number of insects collected per month from the three sampled sites

Pearson correlation coefficient between the average monthly temperature, relative humidity, solar radiation and the total number of insects collected per month, is summarized in table 3.There was significant correlation (0.890)
Table 2: Species richness, diversity and other indices of insects in the three sampled sites, University of Ibadan, Ibadan

\begin{tabular}{lcll}
\hline Indices & $\begin{array}{c}\text { Botanical } \\
\text { Garden }\end{array}$ & $\begin{array}{l}\text { Awba } \\
\text { Dam }\end{array}$ & $\begin{array}{l}\text { PYTP } \\
\text { Farmland }\end{array}$ \\
\hline No. of taxa & 35 & 31 & 23 \\
No of individuals & 709 & 531 & 284 \\
Margalef's index & 2.36 & 4.96 & 2.14 \\
Shannon's Index & 2.05 & 4.36 & 2.14 \\
Evenness's index & 4.13 & 5.62 & 3.15 \\
\hline
\end{tabular}

between months and the total number of insects recorded $(p>0.05)$. The total number of insects collected also increase. In addition, there was partial correlation $(0.374)$ between the total number of insects collected per month and the average solar radiation, while average temperature and relative humidity did not have significant correlation with total number of insects collected per month. 
Table 3: Summary of Pearson Correlation coefficient ( $r$ ) between insect abundance and some environmental parameters

\begin{tabular}{|c|c|c|c|c|c|c|}
\hline & - & Month & $\begin{array}{l}\text { AVERAGE } \\
\text { TEMP. }(0 \mathrm{C}) \\
\end{array}$ & $\begin{array}{c}\text { AVE. REL. } \\
\text { HUMIDITY } \\
(\%) \\
\end{array}$ & $\begin{array}{c}\text { AVE. SOLAR } \\
\text { RADIATION } \\
(\mathrm{MJ} / \mathrm{M} 2)\end{array}$ & $\begin{array}{c}\text { TOTAL } \\
\text { NUMBER OF } \\
\text { INSECTS } \\
\text { COLLECTED }\end{array}$ \\
\hline \multirow[t]{3}{*}{ Month } & $\begin{array}{l}\text { Pcarson } \\
\text { Correlation }\end{array}$ & 1 & -0.497 & -0.783 & 0.540 & $0.890^{*}$ \\
\hline & Sig. (2-tailed) & & 0.316 & 0.065 & 0.269 & 0.018 \\
\hline & $\mathrm{N}$ & 6 & 6 & 6 & 6 & 6 \\
\hline \multirow[t]{3}{*}{$\begin{array}{l}\text { AVERAGE } \\
\text { TEMP. }\left(0^{\circ} \mathrm{C}\right)\end{array}$} & $\begin{array}{l}\text { Pearson } \\
\text { Correlation }\end{array}$ & -0.497 & 1 & 0.216 & -0.626 & -0.066 \\
\hline & Sig. (2-tailed) & 0.316 & & 0.681 & 0.183 & 0.901 \\
\hline & $\mathrm{N}$ & 6 & 6 & 6 & 6 & 6 \\
\hline \multirow{3}{*}{$\begin{array}{l}\text { AVE. REL. } \\
\text { HUMIDITY } \\
(\%)\end{array}$} & $\begin{array}{l}\text { Pearson } \\
\text { Correlation }\end{array}$ & -0.783 & 0.216 & 1 & -0.010 & -0.768 \\
\hline & Sig. (2-tailed) & 0.065 & 0.681 & & 0.984 & 0.075 \\
\hline & $\mathrm{N}$ & 6 & 6 & 6 & 6 & 6 \\
\hline \multirow{3}{*}{$\begin{array}{l}\text { AVE. SOLAR } \\
\text { RADIATION } \\
(\mathrm{MJ} / \mathrm{M} 2)\end{array}$} & $\begin{array}{l}\text { Pearson } \\
\text { Correlation }\end{array}$ & 0.540 & -0.626 & -0.010 & 1 & 0.374 \\
\hline & Sig. (2-tailed) & 0.269 & 0.183 & 0.984 & & 0.465 \\
\hline & $\mathrm{N}$ & 6 & 6 & 6 & 6 & 6 \\
\hline \multirow{3}{*}{$\begin{array}{l}\text { TOTAL } \\
\text { NUMBER OF } \\
\text { INSECTS } \\
\text { COLLECTED }\end{array}$} & $\begin{array}{l}\text { Pearson } \\
\text { Correlation }\end{array}$ & $0.890^{*}$ & -0.066 & -0.768 & 0.374 & 1 \\
\hline & Sig. (2-tailed) & 0.018 & 0.901 & 0.075 & 0.465 & \\
\hline & $\mathrm{N}$ & 6 & 6 & 6 & 6 & 6 \\
\hline
\end{tabular}

*Correlation is significant at the 0.05 level (2- tailed).

\section{DISCUSSION}

The Botanical Garden, Awba Dam and the PYTP Farmland of the University of Ibadan have the potential to support insect diversity considering the outcome of this study. According to Hunter (2002), insects dwell within complex ecosystems and interact with other taxonomic groups and the abiotic environment. It was observed that the PYTP Farmland that was exposed to direct sunlight was drier and warmer and had less number of insects than the Awba Dam Area and the Botanical Garden. Food availability for the insects could result in the presence of certain insects. The relative proportions of insect species as indicated by the results, suggested that the various insect communities resident in the study sites potentially respond differently to the heterogeneity of its environment (Kareiva, 1994; Dauber et al., 2003).
The order Hymenoptera was the most abundant, while members of the order Lepidoptera were the most diverse. Within the Hymenopterans, the genus Componotus of the family Formicidae had the highest number. The high concentration of Hymenopterans may be due to food availability and habitat suitability. This observation can be explained by the findings of Ross (1965), who reported that food was one of the most important factors influencing the abundance and distribution of insects. Insects are found to be more abundant where food is available.

The hymenopterans were dominated by ant species which formed the bulk of the insect biomass. Studies by various workers (Leston, 1973; Room, 1971, 1975) point to the fact that in general, ants tend to dominate the abundance and species richness of the arthropod fauna of many tropical ecosystems.

Badejo (1982) highlighted that the high level 
of social organization among the Hymenopterans, was the basis for their aggregated number. The great diversity of the Lepidopterans may be due to habitat suitability. This finding is consistent with the report of Gullan and Cranston (2004) that Lepidopterans inhabit all terrestrial habitats ranging from desert to rainforest, from lowland grassland to mountain plateaus but almost always associated with higherplants.

The results also showed that Awba Dam area of the University of Ibadan, had the highest species richness and diversity, with Margalef and Shannon's indices values of 4.96 and 4.36, respectively. This may be due to the presence of the water body in the site, as some insects generally breed around water. This finding was in accordance with the report of Sera (2001), where it was reported that insects growth and development are often governed by temperature and moisture content of the area under consideration. The presence of the water body also modify the temperature and relative humidity of the area, thereby making the site to be more conducive for insect fauna, as insects generally prefer humid environment to dry one. The more humid the soil,the nearer are insects to the surface (Little, 1957). Another reason why the Awba Dam recorded the highest abundance and diversity of insect species might be due to the higher tree species found in the area. This observation can be supported by the findings of Adeduntan et al. (2007), where it was reported that the higher the tree species diversity in an area, the higher the insect species diversity. Trees play a vital role in modifying the environment, as they prevent the high intensity of sun rays from reaching the soil, thereby making the temperature and the humidity of the soil more convenient for insect habitation.

The lowest numbers of insects were recorded in the months of February and March, which falls into the dry season during which there was usually shortage of green grasses and food, coupled with high temperature. It was known that only a few number of insects were found during the dry season, due to the fact that the period promotes inactivity in insects. With increasing moisture as it began to rain (from
April onward) and temperatures becoming optimal $\left(15^{\circ} \mathrm{C}-30^{\circ} \mathrm{C}\right)$, a good food base of inorganic nutrients, microbial growth is sure to increase which probably led to the increased insects abundance during the period. It was therefore, not surprising that the bulk of the insects encountered in this study, were recorded during the rainy season.

Pearson correlation coefficient ( $\mathrm{r}$ ) showed a significant relationship between months and the total number of insects obtained. This might be due to the influence of rainfall, as the amount of rainfall increases from February to July. This observation corroborates the findings of Tanka and Tanka (1982), where it was reported that there was a positive relationship between arthropod abundance and rainfall. Temperature and relative humidity showed no significant correlation with the number of insects obtained in the study.

The University of Ibadan (located in the South Western part of Nigeria), has rainforest ecosystem characteristics. Hence, it is rich in insect species and diversity. Although, this study did not cover the dry and wet seasons fully, one can infer from the result obtained in this study that insects were more in abundance during the wet season than in the dry season covered by this study. This was because there were enough plant materials and water, which serve as food and breeding grounds for insects during the wet season. It was also very clear from this study that members of the order Hymenoptera, particularly of the family Formicidae, were the most abundant group of terrestrial insects in the University of Ibadan. This finding might be due to habitat suitability which favours their occurrence.

Further studies in this area of research should explore all the possible methods of collecting insects beyond the methods already used. Also, the period of study should be extended to at least 18 months to properly cover the wet and dry seasons. Furthermore, aquatic insects should also be considered in future studies, so as to have a more comprehensive report of the abundance, distribution and diversity of insects in the University of Ibadan, Ibadan, Nigeria. 


\section{REFERENCES}

Adeduntan, S.A., Tom, I.O and Fuwape, J.A. (2007). Influence of land use systems on diversity and abundance of insects in Akure forest reserves, Ondo State. Nigeria. International Agricultural Research for Development. Pp. 4.

Akoroda, M.O. (2008). Root production techniques and efficiency in Southwest of Nigeria: Cassava as an experimental sample in the University of Ibadan. Fifth edition; 276289.

Aydagnhum, T. (2007). Study on insect diversity of Menagesha forest and Bihere Tsige public park in wet and dry seasons using sweep net [M.S. Thesis], University of Addis Ababa, pp 8-19.

Badejo, M.A. (1982). The distribution and abundance of soil microarthropods in three habitats at the University of Ife. M.Sc. Dissertation. University of Ife, Ile-Ife.

Borror, D.J. and Delong, D.M. (1970). An Introduction to the study of insects. $3^{\text {rd }}$ edition,

Holt, Reinhart and Winston, U.S.A.680708.

Dauber, J., Hirsch, M., Simmering, D., Waldhardt, R., Otte, A. andWolters, V (2003). Landscape structure as an indicator of biodiversity: matrix effects on species richness. Agriculture, Ecosystems and Environment, 98:321-329.

Davis, D.E. (1945). The annual cycle of plants, mosquitoes, birds and mammals in two Brazillian forests. Ecol. Monog., 15:288-298.

Denlinger, D.L. (1980). Seasonal and annual variation of insect abundance in the Nairobi National Park, Kenya. Biotropica, 12: 100-106.

Godfray, H.C., Lewis, O.T., Memmot, J. (1997). Studying insect diversity in the tropics. Phil.

Trans. Biol. Sci., 354: 1811-1824.

Gullan, P. J.and Cranston, P. S. (2004). The insects: an outline of entomology' ( 3 ed.). Wiley Blackwell.,pp. 198-199.

Hunter, M.D (2002). Landscape structure, habitat fragmentation, and the ecology of insects.
Agricultural and Forest Entomology 4, 159-166.

Kareiva, P. (1994). Space: the final frontier for ccological theory. Ecology 75:1.

Leston, D. (1973). The ant mosaic - tropical tree crops and the limiting of pests and diseases. Pest Abstracts and News Summaries, 19: 311341.

Little, V. A. (1957). General and Applied Entomology. Harper and Row Publishers, U.S.A., 424-426.

Oldroyd, H. (1958). Collection, Preserving and Studying Insects. Hutchinson and Co. Ltd. London, 26-62

Omotosho, J.S. (1981).Comparative studies of the reproductive Biology of the two Cichlids Tilapia zilli and Sarotherodon niloticus from small lake in Ibadan,Nig. M.Sc. Thesis, University of Ibadan. 125

Owen, D. F. (1972). Species diversity in tropical Sphingidae and systematic list of species collected in Sierra Leone. J. Nat., Hist. 6: 177194.

Perfecto, I. and Snelling, R. (1995). Biodiversity and the Transformation of a Tropical Agroecosystem: Ants in Coffee Plantations. Ecological Applications Vol.5. No. 4. Pp. 1084-1097.

Room, P. M. (1971). The relative abundance of ant species in Ghana's cocoa farms. Journal of Animal Ecology, 40:735-751.

Room, P. M. (1975). Diversity and organization of the ground foraging ant faunas of forest, grassland and tree crops in Papua, New Guinea. Australian Journal of Zoology, 23:7189.

Ross, H. H. (1965). A Textbook of Entomology. Toppan company ltd. Tokyo. Japan.

Sera E. (2001). Effect of soil properties, review of proposed herbicides. Retrieved from: www.fs.us/rb/invasive plant ei/.../app-ul-soil properties.

Tanka, L.K. and Tanka, S.K. (1982). Rainfall and seasonal changes in arthropod abundance on tropical Oceanic Island. Biotropica 14: 114-123.

Youdeowei, A. (1977). A laboratory manual of Entomolog1: Oxford University Press, Ibadan, Nigeria. 4-7.

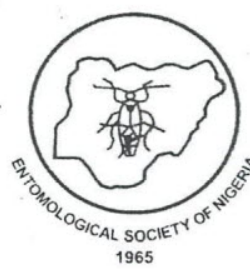

Abah, J. P., K.O.K Popoola* and A.A Hassan

Nigerian Journal of Entomology

Published by the Entomological Society of Nigeria

www.esn.org.ng

ISSN: 0331-0094

Volume 33,2017

pp. 129-137

DOI:10.36108/NJE/7102/33(0151) 